\title{
SHELL BANDING AND COLOR POLYMORPHISM OF THE INTRODUCED SNAIL CEPAEA NEMORALIS (GASTROPODA, HELICIDAE) IN LVIV, WESTERN UKRAINE
}

\author{
N. V. Gural-Sverlova ${ }^{1 \star}$, R. I. Gural ${ }^{1}$, T. V. Rodych ${ }^{2}$ \\ ${ }^{1}$ State Museum of Natural History, NAS of Ukraine \\ Teatralna st., 18, Lviv, 79008 Ukraine \\ E-mail: sverlova@pip-mollusca.org \\ ${ }^{2}$ Lviv National Academy of Arts \\ Kubiyovych st., 38, Lviv, 79011 Ukraine \\ E-mail: rodych.taras@gmail.com \\ ${ }^{*}$ Corresponding author
}

N. V. Gural-Sverlova (https://orcid.org/0000-0002-3892-5338)

R. I. Gural (https://orcid.org/0000-0002-1546-1956)

Shell Banding and Color Polymorphism of the Introduced Snail Cepaea nemoralis (Gastropoda, Helicidae) in Lviv, Western Ukraine. Gural-Sverlova, N. V., Gural, R. I., Rodych, T.V. - The shell coloration was studied in more than three thousand adults of the grove snail, Cepaea nemoralis (Linnaeus, 1758), from 15 colonies discovered in 2019-2020 in Lviv City and in the immediate vicinity of its southern administrative border (Zubra village). In most colonies, relatively light phenotypes prevailed: most often P00000, less often Y00000 or Y00300. In total, more than a third of the collected specimens had the phenotype P00000. Great variability of the phenotypic and genetic structure of this introduced species in the study area was demonstrated, which usually does not have a clear connection with the locations of colonies or with the shading of habitats. This may be due to both random factors (founder effect, gene drift in recently formed colonies), and the relative youth of the colonies. In the future, the obtained data can be used to monitor possible long-term changes in the phenotypic composition of the investigated colonies to assess the potential effect of selective factors on this composition, first of all, climatic selection outside the natural range of $C$. nemoralis.

Key words: terrestrial mollusks, grove snail, introduction, phenotypic composition, Ukraine. 


\section{Introduction}

Cepaea nemoralis (Linnaeus, 1758) is a species of Western European origin (Boettger, 1926; Taylor, 1914), the natural range of which also partially includes Northern and Central Europe. In Ukraine, few reliable findings of this species are known, most of which were made in the west of the country and only in recent years (Gural-Sverlova et al., 2020). In 2019-2020, 15 previously unknown colonies of C. nemoralis were found on the territory of Lviv and in the immediate vicinity of the city's administrative borders. Many of these colonies were quite abundant, which made it possible for the first time to quantitatively analyze the variability of the phenotypic composition within the city. Until now, studies of a similar focus and scale have been carried out only in Northern and Central Europe (Cameron et al., 2009, 2014), i. e. in regions with a less continental climate compared to Ukraine, and in Eastern Europe only for the related species Cepaea hortensis (O. F. Müller, 1774) in Lviv (Sverlova, 2005; Sverlova et al., 2006).

Since many alternative coloring traits (phenes) in C. nemoralis and C. hortensis are inherited (Murray, 1975), the study of their spatial and temporal variability allows one to study population genetic processes, which can be especially interesting for introduced species. Therefore, the main tasks of this publication were: 1) as detailed description of the phenotypic composition in all found colonies as possible — as a basis for its subsequent monitoring; 2 ) assessment of the scale and peculiarities of the present phenotypic and genetic variability of $C$. nemoralis within the city; 3 ) analysis of the possible connection of this variability with the character of habitats inhabited by snails.

\section{Material and methods}

Adult specimens of C. nemoralis (with a reflected apertural margin of the shell) were collected in 20192020 at 14 sites within the administrative boundaries of Lviv (sites 1-14) and one additional site on its southern outskirts (Zubra village, site 15). The locations of the collecting sites are shown in figure 1, and their descriptions are given below. The sites were numbered in the direction from the western border of Lviv to its central part, and then from the center to the south. At a low abundance of snails, the samples also included their empty shells with well-preserved coloration, which made it possible to accurately determine the phenotypes. In total, the shell ground color and banding pattern were scored for more than three thousand specimens of C. nemoralis.

Site 1 - Horodotska Street near the exit to the ring road, between $49^{\circ} 49^{\prime} 14.7^{\prime \prime} \mathrm{N} 23^{\circ} 54^{\prime} 56.6^{\prime \prime} \mathrm{E}$ and $49^{\circ} 49^{\prime} 17.0^{\prime \prime} \mathrm{N} 23^{\circ} 55^{\prime} 09.6^{\prime \prime} \mathrm{E}$, length about $180 \mathrm{~m}$, forest belt along the highway, independent samplings in June (coll. Rodych, along the entire length of the site, designated as "1a") and in July 2020 (coll. Gural-Sverlova, in the central and eastern parts of the site, designated as " $1 \mathrm{~b}$ ”). Since some individuals from the first sample could be included in the second, the second sampling was not taken into account in table 1 in the "Total" column. Table 2 shows the mean frequencies of phenotype groups in two samples. At all other sites, the repeated sampling of the same snails or empty shells was excluded.

Site 2 - Liubinska Street, in front of the old airport terminal, $49^{\circ} 48^{\prime} 59.5^{\prime \prime} \mathrm{N} 23^{\circ} 57^{\prime} 19.6^{\prime \prime} \mathrm{E}$, a round lawn slightly less than $20 \mathrm{~m}$ in diameter with groups of ornamental shrubs planted on it, mainly low-growing junipers, two samplings in July 2020, coll. Gural-Sverlova. Reconstruction and gardening of the site were carried out about 10 years ago. This may be the age of the discovered colony.

Site 3 - Liubinska Street, on the former territory of a military unit, $49^{\circ} 49^{\prime} 08.5^{\prime \prime} \mathrm{N} 23^{\circ} 57^{\prime} 36.0^{\prime \prime} \mathrm{E}$, length about $30 \mathrm{~m}$, shaded plot with dense woody vegetation, several samplings in May 2020, coll. Rodych.

Site 4 - Syhnivka Street, household plot near the building No. 48, 4949' 31.4" N 2357'27.9" E, tall ornamental shrubs (Kerria japonica), wild grapes on a wire fence, several samplings in July 2020, coll. Gural-Sverlova. Seven adults and several juveniles were found along a fragment of the fence about $4 \mathrm{~m}$ long. No C. nemoralis has yet been found at neighboring sites. The nearest colony (Site 5) is at a distance of about $200 \mathrm{~m}$.

Site 5 - Liutneva Street, around the mansion No. 33, 4949'33.0" N 235' $43.1^{\prime \prime}$ E, length about $30 \mathrm{~m}$, various ornamental plants along the fence, several samplings in July 2020, coll. Gural-Sverlova. Apparently, the colony was formed most recently, and snails are just beginning to penetrate the household plots of neighboring mansions.

Site 6 - near the intersection of Horodotska Street with Ivan Bahrianyi Street and Rivna Street, between $49^{\circ} 49^{\prime} 48.4^{\prime \prime} \mathrm{N} 23^{\circ} 58^{\prime} 35.2^{\text {"E }}$ (49 $49^{\prime} 54.1^{\prime \prime} \mathrm{N} 23^{\circ} 58^{\prime} 29.9^{\prime \prime} \mathrm{E}, 49^{\circ} 49^{\prime} 54.9^{\prime \prime} \mathrm{N} 23^{\circ} 58^{\prime} 33.8^{\prime \prime} \mathrm{E}$ and $49^{\circ} 49^{\prime} 51.2^{\prime \prime} \mathrm{N}$ $23^{\circ} 58^{\prime} 36.6^{\prime \prime} \mathrm{E}$, length about $150 \mathrm{~m}$, household plots of mansions and roadsides with different vegetation and lighting, 28.06.2020, coll. Gural-Sverlova.

Site 7 - near the intersection of General Chuprynka Street with Osyp Makovei Street and Lonhyn Tsehelskyi Street, between $49^{\circ} 49^{\prime} 21.5^{\prime \prime} \mathrm{N} 24^{\circ} 00^{\prime} 00.1^{\prime \prime} \mathrm{E}, 49^{\circ} 49^{\prime} 21.5^{\prime \prime} \mathrm{N} 24^{\circ} 00^{\prime} 03.4^{\prime \prime} \mathrm{E}, 49^{\circ} 49^{\prime} 19.3^{\prime \prime} \mathrm{N} 23^{\circ} 59^{\prime} 58.7^{\prime \prime} \mathrm{E}$ and $49^{\circ} 49^{\prime} 18.5^{\prime \prime} \mathrm{N} 24^{\circ} 00^{\prime} 02.8^{\prime \prime} \mathrm{E}$, length about $60 \mathrm{~m}$, plots with different vegetation and lighting near mansions and apartment buildings, several samplings in Juny 2020, coll. Gural-Sverlova.

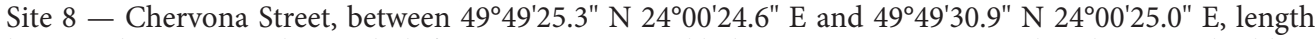
slightly more than $100 \mathrm{~m}$, plots with different vegetation and lighting near mansions and multi-storey building No. 26 on Princess Olga Street, several samplings in July 2020, coll. Gural-Sverlova.

Site 9 - Dmytro Vitovskyi Street, near buildings No. 30 and 34 and on the adjacent edge of the Citadel Park, between $49^{\circ} 49^{\prime} 47.1^{\prime \prime} \mathrm{N} 24^{\circ} 01^{\prime} 35.8^{\prime \prime} \mathrm{E}, 49^{\circ} 49^{\prime} 48.8^{\prime \prime} \mathrm{N} 24^{\circ} 01^{\prime} 32.5^{\prime \prime} \mathrm{E}$ and $49^{\circ} 49^{\prime} 47.8^{\prime \prime} \mathrm{N} 24^{\circ} 01^{\prime} 30.6^{\prime \prime} \mathrm{E}$, length up to 
$80 \mathrm{~m}$, most of the site is a steep southern slope shaded by tall trees, multiple samplings in June 2020, coll. Gural-Sverlova and Gural. The site is separated from the subsequent one by a hill with the Citadel Park, in the upper part of which $C$. nemoralis has not yet been found.

Site 10 - Kalicha Hora Street, around the former villa "Zasvittia" (No. 24), between $49^{\circ} 50^{\prime} 05.4^{\prime \prime} \mathrm{N} 24^{\circ} 01^{\prime} 37.6^{\prime \prime} \mathrm{E}$ and $49^{\circ} 50^{\prime} 07.7^{\prime \prime} \mathrm{N}$ $24^{\circ} 01^{\prime} 33.6^{\prime \prime} \mathrm{E}$, length about $70 \mathrm{~m}$, on hawthorns planted along the brick fence of the villa and at greened plots near neighboring apartment buildings, multiple samplings in August 2019 and May-June 2020, coll. GuralSverlova and Gural. In a previous publication (Gural-Sverlova et al., 2020), the site was designated as "Lviv-3". When analyzing the material collected on it in 2019 (Gural-Sverlova et al., 2020: table 1), several individuals of C. hortensis with a pink shell and a dark lip, locally found at the same site, were mistaken for C. nemoralis. In this article, they have been excluded from the calculations.

Site 11 - Volodymyr Hnatiuk Street,

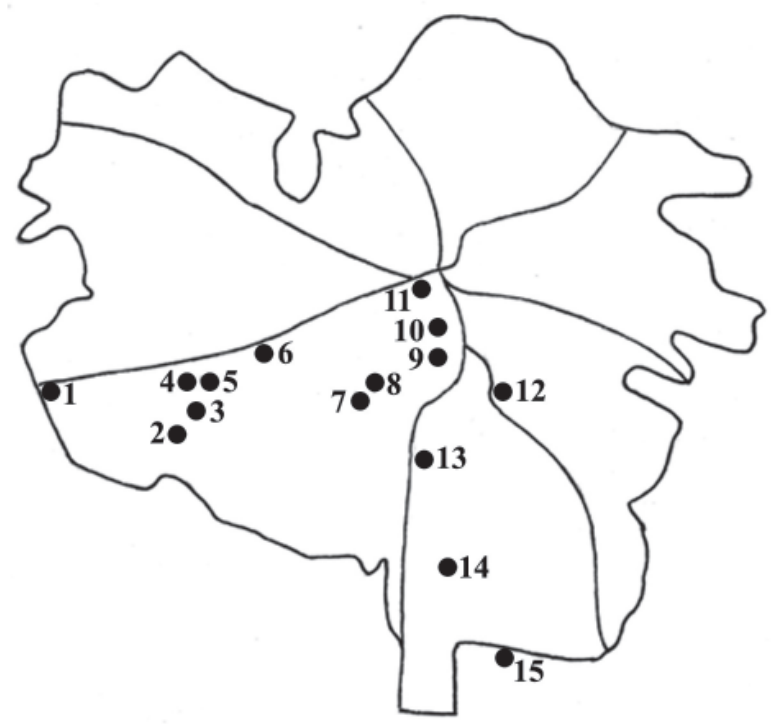

Fig. 1. The locations of the collecting sites in Lviv.

near the monument to the dead law enforcement officers, 4950'29.8" N 2401'21.0" E, two small fragments of a lawn 10-15 $\mathrm{m}$ long and up to $5 \mathrm{~m}$ wide with groups of low-growing coniferous ornamental plants, mainly junipers, several samplings in late June and early July 2020, coll. Gural-Sverlova and Gural. The monument was opened at the end of 1999, after which the area around it was landscaped. Therefore, the age of the discovered colony may be about 20 years.

Site 12 - between Zelena Street and Krymska Street, on the edge of the Snopkiv Park, between $49^{\circ} 49^{\prime} 28.6^{\prime \prime} \mathrm{N} 24^{\circ} 02^{\prime} 41.0^{\prime \prime} \mathrm{E}, 49^{\circ} 49^{\prime} 27.8^{\prime \prime} \mathrm{N} 24^{\circ} 02^{\prime} 56.9^{\prime \prime} \mathrm{E}$ and $49^{\circ} 49^{\prime} 26.8^{\prime \prime} \mathrm{N} 24^{\circ} 02^{\prime} 45.6^{\prime \prime} \mathrm{E}$, length about $200 \mathrm{~m}$, mostly household plots of mansions and adjacent open areas with tall grass (Gural-Sverlova et al., 2020: fig. 2A), multiple samplings in July 2019 and from May to July 2020, coll. Gural-Sverlova and Gural. In a previous publication (Gural-Sverlova et al., 2020), the site was designated as "Lviv-2".

Site 13 - between Ivan Chmola Street (mostly) and Luhanska Street (several individuals), around the territory of the former garden center, between $49^{\circ} 48^{\prime} 52.1^{\prime \prime} \mathrm{N} 24^{\circ} 01^{\prime} 30.2^{\prime \prime} \mathrm{E}, 49^{\circ} 48^{\prime} 52.6^{\prime \prime} \mathrm{N} 24^{\circ} 01^{\prime} 12.6^{\prime \prime} \mathrm{E}$, $49^{\circ} 48^{\prime} 42.9^{\prime \prime} \mathrm{N} 24^{\circ} 01^{\prime} 20.5^{\prime \prime} \mathrm{E}$ and $49^{\circ} 48^{\prime} 41.6^{\prime \prime} \mathrm{N} 24^{\circ} 01^{\prime} 29.3^{\prime \prime} \mathrm{E}$, length about $250 \mathrm{~m}$, mostly in places shaded by tall trees (Gural-Sverlova et al., 2020: fig. 1A), multiple samplings from June to September 2019 and from April to September 2020, coll. Gural-Sverlova and Gural. In a previous publication (Gural-Sverlova et al., 2020), the site was designated as "Lviv-1".

Site 14 - Khutorivka Street near the entrance to the Shuvar market, wasteland next to the garden center,

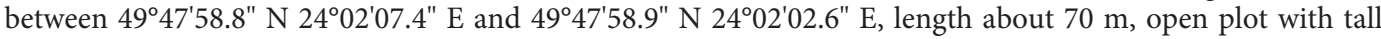
grass, the remains of grapes on a wire fence, 23.06.2020, coll. Gural-Sverlova.

Site 15 - Pustomyty District, Zubra village (territory adjacent to the southern outskirts of Lviv), between $49^{\circ} 46^{\prime} 42.7^{\prime \prime} \mathrm{N} 24^{\circ} 03^{\prime} 08.4^{\prime \prime} \mathrm{E}$ and $49^{\circ} 46^{\prime} 43.4^{\prime \prime} \mathrm{N} 24^{\circ} 03^{\prime} 01.4^{\prime \prime} \mathrm{E}$, length up to $100 \mathrm{~m}$, wasteland between houses with tall grass, on one edge with sparse bushes and young trees (Gural-Sverlova et al., 2020: fig. 1C), several samplings in May-June 2019 and June 2020, coll. Gural-Sverlova.

In order to avoid the influence of random factors of the collection on the calculation results, we excluded from them the sites where less than 50 alive adult snails or their empty shells were collected. These were sites 4 and 5 , apparently only recently colonized by $C$. nemoralis, as evidenced by both the low abundance of snails and the extremely limited space at which they were recorded (see descriptions of the corresponding sites).

To analyze the possible influence of the nature of the biotopes inhabited by snails on the phenotypic composition of their colonies, all the studied sites (with the exception of the above-mentioned sites 4 and 5) were divided into three groups, designated as 1) "open", with good insolation, most of the territory of which was not shaded by trees or tall bushes, less often with their complete absence; 2) "shaded", completely or almost completely shaded by tall trees, often with dense tree-shrub undergrowth; 3) "mosaic", at which, in a relatively small area, places with different vegetation and shading alternated, and which therefore could not be attributed to any of the previous types. In addition to shading by trees, we also took into account the shading of sites by houses (especially multi-storey ones), solid (not wire) fences, etc. Although the territory of the former garden center (site 13) also had open plots, snails were collected mainly in places shaded by tall trees along the edge of this territory and near it. Therefore, site 13 was assigned to the group of shaded biotopes.

Phenotypes were scored based on the ground color of the shells and the banding pattern of their ultimate whorl according to the standard method (Clarke, 1960). Spiral dark bands were designated by Arabic 


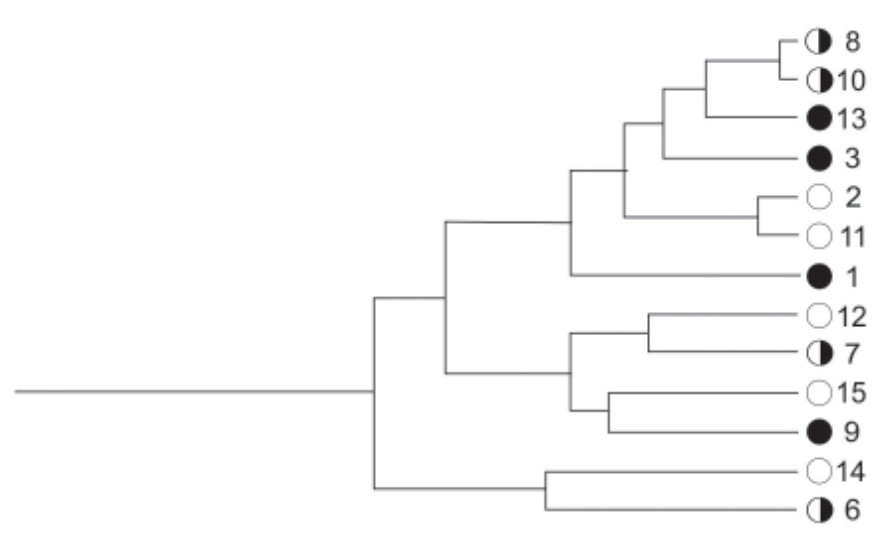

Fig. 2. The similarity of the phenotypic (top) and genetic (bottom) composition of the studied samples. Open habitats are denoted by light circles, shaded by black, and mosaic by black and white.

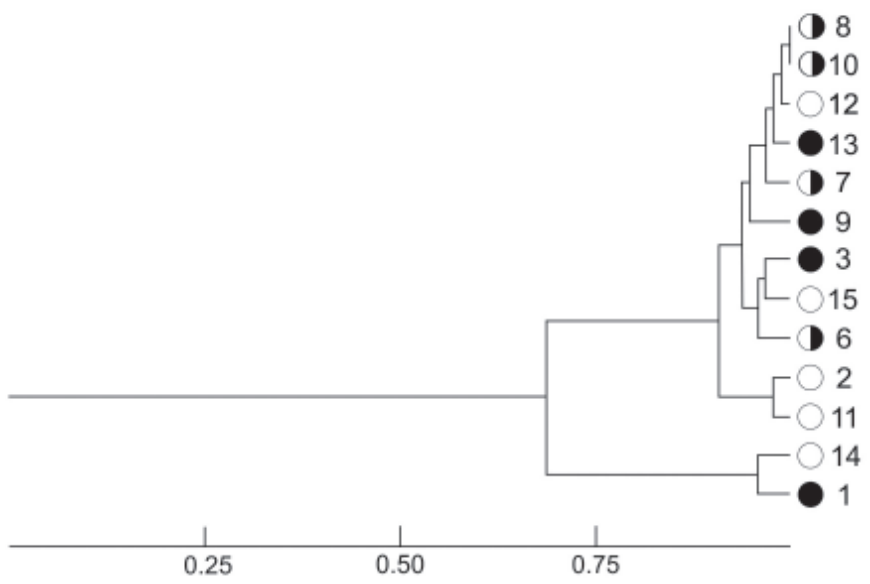

numerals from 1 to 5 , counting them from the apex to the base of the shell. The absence of band(s) was indicated as " 0 " in place of the corresponding numeral(s). The fusion of adjacent bands was indicated with parentheses. The bands were considered to be fused if they were fully or partially merged for no less than a quarter of a whorl before the aperture.

The presence of additional weak, often blurry bands (modification), occasionally appearing on shells with a genetically determined phenotype 00000, 00300, or 00345, was indicated by square brackets. During further sorting of phenotypes into groups (see below), such bands were not taken into account. Barely noticeable traces of bands, sometimes visible only near the shell aperture, were not specially designated in the formulas of phenotypes. The shell ground color was designated as $\mathrm{Y}-$ yellow, $\mathrm{P}-$ pink, $\mathrm{B}$ - brown. White or nearly white shells without yellow pigment have traditionally been classified as yellow.

In the subsequent analysis of the phenotypic composition of the studied colonies of $C$. nemoralis, the phenotypes distinguished by the shell banding (table 1) were combined into 4 groups: 1) unbaded - in this study were represented exclusively by the phenotype 00000; in general may include also some genetically unbanded shells with 1-2 unclear bands (modifications); 2) mid-banded - the same for the phenotype 00300: 3) three-banded - all shells with three lower bands, discrete or fused, occasionally with one or two fuzzy upper bands (modifications); 4) five-banded - the phenotype 12345 and its variations with the absence or fusion of some bands. Since in C. nemoralis the absence/presence of bands on the shell and its ground color can be inherited linked (Murray, 1975), when comparing the phenotypic composition of the studied colonies, these groups were considered in combination with the ground color (table 2).

To formally assess the intensity of shell pigmentation in colonies, all phenotypes were divided into 3 groups: 1) "light", including phenotypes Y00000, Y00300, P00000, P00300 and their modifications; 2) "medium", including all yellow and pink three-banded shells as well as five-banded shells without band fusion; 3) "dark", including brown shells (in Lviv, represented exclusively by the phenotype B00000) as well as yellow and pink five-banded shells with fused bands. Shells from the first group are characterized not only by light, but also relatively homogeneous coloration. The second group is characterized by a combination of contrasting dark and light fragments (dark discrete bands separated by narrow light gaps, as well as a combination of a light top and dark bottom in three-banded shells). In the third group, the coloration of the five-banded shells becomes not only darker, but also more homogeneous (less banded) due to the band fusion.

To assess the variability of the phenotypic composition of C. nemoralis between Lviv, the inbreeding coefficient Fst was used, calculated based on the frequencies of phenotypic manifestation of some inherited traits (Cameron et al., 2009) or the frequencies of the corresponding alleles. In the first case, the frequencies of unbanded shells as well as the shells with different ground color were calculated from the total sample size, the frequencies of shells with a central band from the number of banded shells, and the frequencies of three-banded shell from the number of multi-banded shells (Cameron et al., 2009, 2014), which corresponds to the known data on the character of inheritance of the mentioned traits (Murray, 1975). Allele frequencies were calculated conditionally, using the Hardy-Weinberg formula for an ideal panmictic population.

The phenotypic similarity of the studied samples, presented in the form of a dendrogram in figure 2, was calculated by the formula: 


$$
\mathrm{r}=\sqrt{\mathrm{p}_{1} \mathrm{q}_{1}}+\sqrt{\mathrm{p}_{2} \mathrm{q}_{2}}+\ldots+\sqrt{\mathrm{pmq}_{\mathrm{m}}}
$$

where $p_{1}, p_{2} \ldots p_{i}$ are the frequencies of phenotype groups at one site; $q_{1}, q_{2} \ldots q_{i}-$ frequencies of the same groups at another site. The frequencies of 9 phenotype groups, distinguished by the combination of the ground color and the number of bands on the shell (table 2), were used for calculations. Genetic similarity was assessed by the mean value obtained for the allele frequencies of four genes responsible for the ground color of the shell, the absence of all bands on it, the absence of all bands except for the central one, and the absence of the two upper bands. Then, the average was calculated from the four values obtained.

It is considered that the diameter of the panmictic unit for C. nemoralis is 50-60 m (Lamotte, 1951, cited according to Jones et al., 1977), according to other data - up to $100 \mathrm{~m}$ (Schnetter, 1950) in the absence of natural or anthropogenic (Sverlova, $2002 \mathrm{a}$ ) barriers preventing the free locomotion of snails. The sizes of the sites studied by us sometimes exceeded the mentioned values by several times, but the snails inhabiting them had a common origin, could freely move within the sites, and were reliably spatially isolated from other known colonies of $C$. nemoralis in Lviv. We have used the term "colony" to denote such aggregations of snails, although in most cases (with the exception of sites 4, 5 and possibly 3 ) they could be considered already established populations.

The materials used in this study were partially deposited in the malacological collection of the State Museum of Natural History of the National Academy of Sciences of Ukraine in Lviv. Photos of live snails and their shells with different coloration are posted on one of the museum's Internet resources (Gural-Sverlova, Gural, 2012-2020).

\section{Results}

In total, in 15 studied colonies of $C$. nemoralis a large variety of phenotypes was recorded (table 1), most of which were of hereditary nature, and some rare coloration variants should obviously be considered as modifications. The latter refers primarily to shells with poorly developed, indistinct bands, indicated by square brackets (see Material and methods). More than a third of all collected specimens had one phenotype (P00000).

At all sites, polymorphism in the shell ground color was recorded (table 2), although in the Zubra (site 15) only a single individuals had pink shells (table 1). On the other hand, at site 2 , more than $90 \%$ of snails had pink shells, which was associated with a very high proportion of the phenotype P00000 (about three quarters of all collected snails). In general, snails with a yellow or pink ground color of the shell predominated in the studied colonies equally often (table 2).

Brown shells, represented by one phenotype B00000, were found at only three sites (table 2), although at site 9 , a third of the collected snails had such shell ground color. At the same site, a large variability of the intensity of the brown color was observed - from very dark to almost white with a slight brownish tint in few specimens (Gural-Sverlova, Gural, 2012-2020). At the other two sites, only individuals with dark brown shells were found (Gural-Sverlova et al., 2020, fig. 2, F).

At site 14, not only all brown shells were unbanded, but all unbanded ones were brown (table 2), which may indicate a completely linked inheritance of these two dominant traits. The only exception was five unbanded shells of pink or yellow color, which we classified as modifications from the phenotypes P00300 and Y00300 (table 1). On the periphery of whorls, each of these shells had a light spiral band (Gural-Sverlova, Gural, 2012-2020). A similar band, much lighter than the ground color, is sometimes clearly visible under the dark central band in the phenotype 00300, but not found in 00000. In one of the abovementioned shells, faint traces of the missing central dark band were also noticeable near the aperture (Gural-Sverlova, Gural, 2012-2020).

In addition to yellow, pink, and brown shells, white shells without traces of yellow, pink, or brown pigment were also found in Lviv (Gural-Sverlova, Gural, 2012-2020), which were combined with yellow ones in the calculations (see Material and methods). In most samples, they were either absent or were represented by a few individuals. However, at site $6,20 \%$ of the snails in the sample had white shells. And among specimens classified as Y00300, those were almost $30 \%$.

In contrast to the ground color, a number of the samples were monomorphic in one of the three genes responsible for the absence (dominant trait) of all bands on the shell, two upper and 


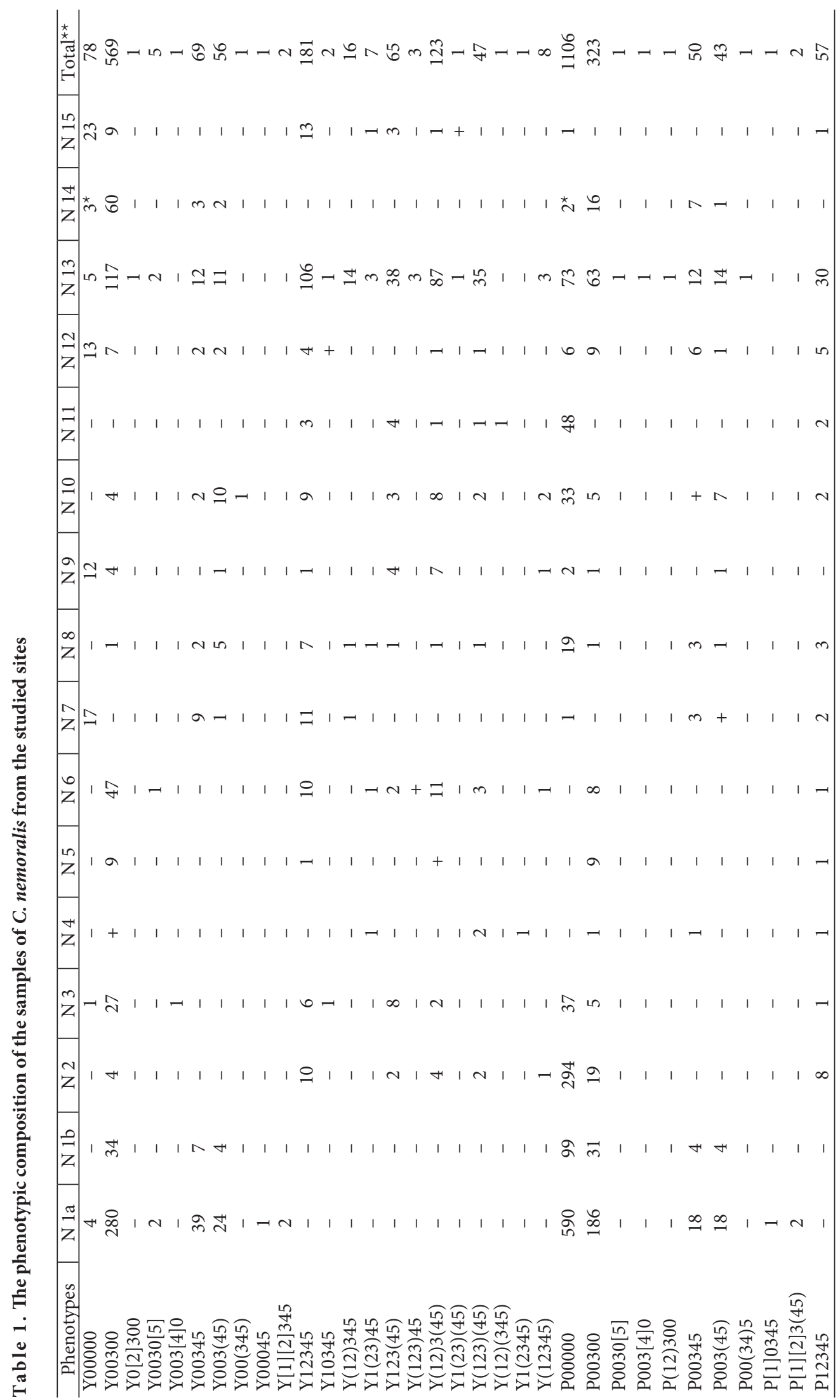




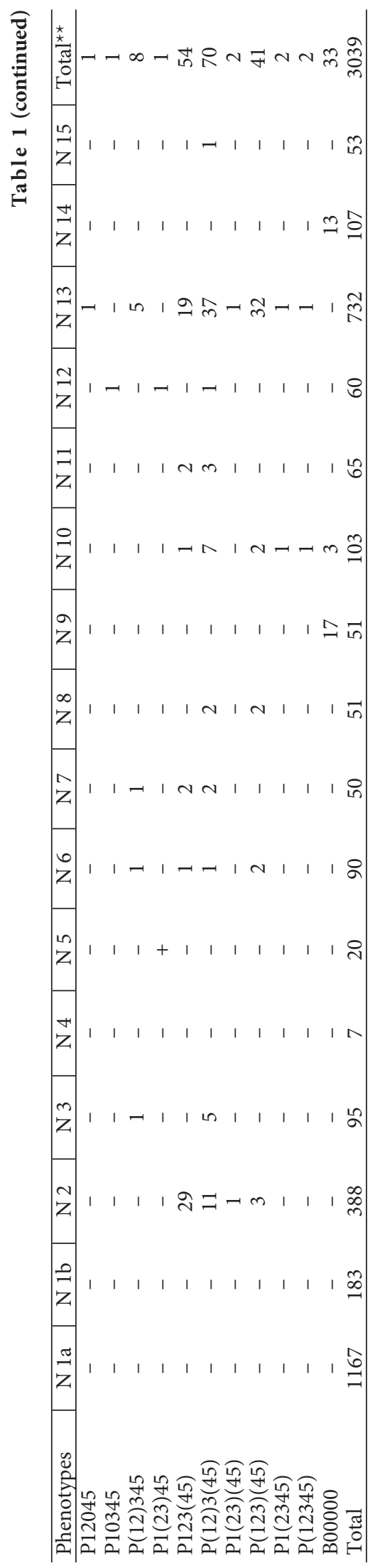

two lower bands, or only two upper bands (Murray, 1975), which leads to the formation of unbanded, mid-banded and three-banded shells respectively. In most cases, such samples did not contain specimens with a dominant allele of one of the genes listed above, and occasionally two of them (table 3 ).

At site 10, three adults were found with weakly pigmented (light brown or almost pink) or colorless and transparent (hyalosonate) bands. The lip of these shells was also not typically light for C. nemoralis - from pinkish to almost wholly white (Gural-Sverlova, Gural, 2012-2020). One juvenile with a shell diameter of no more than $1 \mathrm{~cm}$ and with hyalosonate bands was also found at site 8 .

Among the groups of phenotypes distinguished by the combination of the ground color and the number of bands (table 2), one of the four lightest variants of shell coloration (see Material and methods) prevailed in almost all cases, most often P00000, less often Y00000 or Y00300. The total frequency of the above mentioned phenotypes and P00300, on average, was slightly higher at open sites, the shells with "medium" intensity and clearly expressed heterogeneity of coloration - at sites with heterogeneous vegetation and alternating open and shaded places, and the darkest phenotypes - in shaded habitats, although these differences did not always reach a statistically significant level (table 4). The average frequencies of yellow, unbanded and mid-banded shells did not show statistically significant differences between open, shaded and "mosaic" habitats, although the latter had more yellow banded shells (table 4).

When constructing dendrograms of phenotypic and genetic similarity of the studied colonies (fig. 2), the greatest similarity was often demonstrated by samples collected in different parts of the city and in different types of habitats. In the first case, all samples were divided into three main groups: 1) with a pronounced predominance of Y00300 (more than half of the specimens in the samples) and the absence of Y00000 and P00000 (sites 6 and 14); 2) with high frequencies Y00000from 22 to $43 \%$ in comparison with $0-1 \%$ in other samples (sites 7, 9, 12 and 15); 3) others, most often with a predominance of P00000. In the second case, six sites located in the central part of the city (sites 9 and 10) and slightly to the south (sites 7, 8,12 and 13) were united into one group. Only at these sites, with the exception of site 7 , were collected the samples that were not monomorphic for any of the three genes responsible for the complete 
Table 2. Percentages of phenotype groups at the sites with different degrees of shading

\begin{tabular}{|c|c|c|c|c|c|c|c|c|c|c|c|c|c|c|c|c|}
\hline \multirow{2}{*}{$\begin{array}{l}\text { Phenotype } \\
\text { groups }\end{array}$} & \multicolumn{6}{|c|}{ Open } & \multicolumn{5}{|c|}{ Shaded } & \multicolumn{5}{|c|}{ Mosaic } \\
\hline & N 2 & N 11 & $\mathrm{~N} 12$ & $\mathrm{~N} 14$ & N 15 & mean & N 1 & N 3 & $\mathrm{~N} 9$ & $\mathrm{~N} 13$ & mean & N 6 & N 7 & N 8 & N 10 & mean \\
\hline \multicolumn{17}{|c|}{ Ground color and banding } \\
\hline $\mathrm{Y}-0$ & - & - & 21.7 & - & 43.4 & 13.0 & 0.2 & 1.1 & 23.5 & 0.7 & 6.4 & - & 34.0 & - & - & 8.5 \\
\hline Y-1 & 1.0 & - & 11.7 & 58.9 & 17.0 & 17.7 & 21.4 & 29.5 & 7.8 & 16.4 & 18.8 & 53.3 & - & 2.0 & 3.9 & 14.8 \\
\hline Y-3 & - & - & 6.7 & 4.7 & - & 2.3 & 5.8 & - & 2.0 & 3.1 & 2.7 & - & 20.0 & 13.7 & 12.6 & 11.6 \\
\hline Y-5 & 4.9 & 15.4 & 10.0 & - & 34.0 & 12.8 & - & 17.9 & 25.5 & 39.8 & 20.8 & 31.1 & 24.0 & 23.5 & 23.3 & 25.5 \\
\hline P-0 & 75.8 & 73.8 & 10.0 & - & 1.9 & 32.3 & 52.3 & 38.9 & 3.9 & 10.0 & 26.3 & - & 2.0 & 37.3 & 32.0 & 17.8 \\
\hline P-1 & 4.9 & - & 15.0 & 16.8 & - & 7.3 & 16.4 & 5.3 & 2.0 & 9.0 & 8.2 & 8.9 & - & 2.0 & 4.9 & 3.9 \\
\hline P-3 & - & - & 11.7 & 7.5 & - & 3.8 & 3.9 & - & 2.0 & 3.7 & 2.4 & - & 6.0 & 7.8 & 6.8 & 5.2 \\
\hline P-5 & 13.4 & 10.8 & 13.3 & - & 3.8 & 8.3 & - & 7.4 & - & 17.3 & 6.2 & 6.7 & 14.0 & 13.7 & 13.6 & 12.0 \\
\hline B-0 & - & - & - & 12.1 & - & 2.4 & - & - & 33.3 & - & 8.3 & - & - & - & 2.9 & 0.7 \\
\hline $\begin{array}{l}\text { Number } \\
\text { of groups }\end{array}$ & 5 & 3 & 8 & 5 & 5 & 5.2 & 6 & 6 & 8 & 8 & 7.0 & 4 & 6 & 7 & 8 & 6.3 \\
\hline
\end{tabular}

of groups

\begin{tabular}{|c|c|c|c|c|c|c|c|c|c|c|c|c|c|c|c|c|}
\hline \multicolumn{17}{|c|}{ Ground color } \\
\hline Yellow & 5.9 & 15.4 & 50.0 & 63.6 & 94.3 & 45.8 & 27.4 & 48.4 & 58.8 & 60.0 & 48.6 & 84.4 & 78.0 & 39.2 & 39.8 & 60.4 \\
\hline Pink & 94.1 & 84.6 & 50.0 & 24.3 & 5.7 & 51.7 & 72.6 & 51.6 & 7.8 & 40.0 & 43.0 & 15.6 & 22.0 & 60.8 & 57.3 & 38.9 \\
\hline Brown & - & - & - & 12.1 & - & 2.4 & - & - & 33.3 & - & 8.3 & - & - & - & 2.9 & 0.7 \\
\hline \multicolumn{17}{|c|}{ Number of bands } \\
\hline Unbanded & 75.8 & 73.8 & 31.7 & 12.1 & 45.3 & 47.7 & 52.5 & 40.0 & 60.8 & 10.7 & 41.0 & - & 36.0 & 37.3 & 35.0 & 27.1 \\
\hline $\begin{array}{l}\text { Mid- } \\
\text { banded }\end{array}$ & 5.9 & - & 26.7 & 75.7 & 17.0 & 25.1 & 37.8 & 34.7 & 9.8 & 25.4 & 26.9 & 62.2 & - & 3.9 & 8.7 & 18.7 \\
\hline $\begin{array}{l}\text { Three- } \\
\text { banded }\end{array}$ & - & - & 18.3 & 12.1 & - & 6.1 & 9.7 & - & 3.9 & 6.8 & 5.1 & - & 26.0 & 21.6 & 19.4 & 16.7 \\
\hline $\begin{array}{l}\text { Five- } \\
\text { banded }\end{array}$ & 18.3 & 26.2 & 23.3 & - & 37.7 & 21.1 & - & 25.3 & 25.5 & 57.1 & 27.0 & 37.8 & 38.0 & 37.3 & 36.9 & 37.5 \\
\hline
\end{tabular}

Note. The maximum values are bold and underlined.

or partial absence of bands on the shells of C. nemoralis (table 3). In both cases, a great similarity showed plots 2 and 11, where snails live under similar conditions, at small isolated open plots with regularly mowed lawns and groups of low-growing junipers (see Material and methods).

The calculated values of the inbreeding coefficient Fst are given in table 5. For all the examined inherited traits, they were higher when used in the calculations the frequencies of their phenotypic manifestation, rather than the allele frequencies of the corresponding genes. The smallest contribution to the phenotypic and genetic variability of $C$. nemoralis within Lviv is made by such traits as the brown color of the shell (a rare trait) and the complete absence of bands on it (a common trait).

\section{Discussion}

The first attempt to introduce C. nemoralis to Lviv was made at the end of the 19th century (Łomnicki, 1899). This, however, did not lead to the formation of established colonies in the places where snails were released, which would have survived to this day (GuralSverlova et al., 2020). At the turn of the 20th and 21st centuries, only one colony of this species was known in one of the city parks, characterized by a low abundance and poor phenotypic composition (Sverlova, 2002 b; Sverlova et al., 2006), by now almost completely extinct (Gural-Sverlova, Savchuk, 2019). A number of the colonies of C. nemoralis found in Lviv in 2019 and 2020 and described in this article, obviously, have no relation to it, which is confirmed by a richer phenotypic composition, first of all, by the presence of snails with unbanded and/or five-banded shells at all sites (Gural-Sverlova et al., 2020).

Therefore, recently discovered colonies should be considered as a result of a later introduction (or, more likely, several independent introductions) together with ornamental 
Table 3. Samples monomorphic in one trait

\begin{tabular}{c|ccc|c}
\hline \multirow{2}{*}{$\begin{array}{c}\text { Inherited pheno- } \\
\text { typic traits }\end{array}$} & \multicolumn{2}{|c|}{ Number of samples monomorphic by } & \multirow{2}{*}{ Site numbers } \\
\cline { 2 - 3 } & its presence & its absence & $(4),(5), 6$ \\
Unbanded & - & $1(3)$ & 7,11 \\
Mid-banded & - & 2 & $1-3,(5), 6,11,14,15$ \\
Three-banded & 2 & $5(6)$ & $1-3,(4),\left(5^{*}\right), 6^{*}, 7,11^{\star}, 14,15$ \\
Any of them & 2 & $6(8)$ & \\
\hline
\end{tabular}

Note. In parentheses, taking into account two small samples at sites 4 and 5; an asterisk denotes sites, the samples from which were monomorphic in two traits.

plants, which is confirmed by the findings of two colonies near garden centers, working (site 14) or recently closed (site 13). Already Boettger (1926) drew attention to the close connection between the expansion of the range of $C$. nemoralis and the garden culture. It is impossible to determine the exact age of most of the colonies found by us, in some cases it can be indirectly estimated at 10-20 years (see descriptions of sites 2 and 11 in Material and methods). This is in good agreement with the end of a strong economic decline in Ukraine in the 1990s and the beginning of an active and almost uncontrolled import of garden and ornamental plants from other European countries.

It is considered that Fst values may depend on the time of colonization of cities by C. nemoralis (Cameron et al., 2009, 2014). Our results (table 5) are comparable with the data obtained in other regions of Europe for cities, the active colonization of which by C. nemoralis began only in the last decades (Cameron et al., 2009, 2014). However, the high values of this index calculated for Lviv may be associated not only with the relative youth of the studied colonies, but also with their complete isolation from each other and, possibly, with different origins. In the future, the phenotypic and genetic composition of such isolated colonies can become more similar only if they change in the same direction under the influence of climatic selection, the influence of which theoretically should increase outside the natural range.

The mosaic distribution of the frequencies of the main phenotype groups over the study area, which often leads to a greater phenotypic similarity of distant rather than neighboring colonies of C. nemoralis in Lviv (fig. 2), is quite expected for colonies that arise not as a result of own locomotor activity of mollusks, but solely as a result of the transfer of a certain number of snails or their eggs by humans. In our opinion, the similarity of the genetic composition of almost all colonies located in the central part of Lviv and a little further south of it is more interesting (see Results). The most likely reasons for this could be the following:

Table 4. Differences in the percentages of some traits and phenotype groups at the sites with different shading

\begin{tabular}{|c|c|c|c|c|c|c|c|c|c|}
\hline \multirow{2}{*}{$\begin{array}{l}\text { Traits or phe- } \\
\text { notype groups }\end{array}$} & \multicolumn{2}{|c|}{ Open $(\mathrm{O})$} & \multicolumn{2}{|c|}{ Shaded (Sh) } & \multicolumn{2}{|c|}{ Mosaic (M) } & \multicolumn{3}{|c|}{$\begin{array}{c}\text { Differences } \\
\text { (Mann-Whitney test) }\end{array}$} \\
\hline & $\min -\max$ & mean & $\min -\max$ & mean & $\min -\max$ & mean & $\mathrm{O}-\mathrm{Sh}$ & $\mathrm{O}-\mathrm{M}$ & M-Sh \\
\hline \multicolumn{10}{|c|}{ Some inherited phenotypic traits } \\
\hline Yellow & $5.9-94.3$ & 45.8 & $27.4-60.0$ & 48.6 & $39.2-84.4$ & 60.4 & 10 & 8 & 6 \\
\hline Unbanded & $12.1-75.8$ & 47.7 & $10.7-60.8$ & 41.0 & $0-37.3$ & 27.1 & 8 & 6 & 3 \\
\hline Mid-banded* & $0-86.2$ & 36.1 & $25.0-79.6$ & 47.7 & $0-62.2$ & 20.5 & 8 & 6.5 & 3 \\
\hline \multicolumn{10}{|c|}{ Intensity of shell coloration (phenotype groups) } \\
\hline Light & $58.3-81.7$ & 70.4 & $36.1-90.3$ & 59.6 & $36.0-62.2$ & 45.0 & 8 & $1^{\star *}$ & 6 \\
\hline Medium & $4.6-35.0$ & 17.2 & $5.9-25.7$ & 12.4 & $12.2-52.0$ & 33.9 & 9 & 3 & $1^{\star *}$ \\
\hline Dark & $6.7-18.5$ & 12.5 & $0-56.9$ & 28.0 & $12.0-29.1$ & 21.1 & 6 & 4 & 7 \\
\hline
\end{tabular}

Note. ${ }^{\star}$ Calculated from the number of banded shells, ${ }^{* *}$ significant at $\mathrm{p}=0.05$. 
1) all the mentioned sites, or at least part of them, could have been colonized by individuals from a common origin, for example, from a large garden center located near the city center (near site 13), which worked there from the 20th century until 2018; 2) these sites were colonized by a larger number of founder individuals (including also egg clutches located among the roots of seedlings) with a greater genetic and phenotypic diversity, which prevented the accidental disappearance or monomorphization of some hereditary traits.

Indirect confirmation of the first hypothesis could be the discovery at some of these sites also individuals of $C$. hortensis with a shell coloration not typical for Lviv: yellow banded (sites $9,10,13$ ), pink in combination with a dark lip (about $20 \%$ at site 10 , as well as one anatomically verified specimen at site 7), which suggests a possible joint introduction of these two species. Numerous colonies of $C$. hortensis in Lviv, formed by the descendants of mollusks that were introduced to Western Ukraine already in the 20th century (Sverlova et al., 2006), are represented by only three variants of shell coloration: yellow unbanded, white unbanded, and white banded. On the other hand, at some sites there are the coloration variants that are absent near the garden center: brown shells in C. nemoralis (sites 9 and 10), pink shells with a dark lip in C. hortensis (see above). Thus, this garden center is hardly worth considering as a potential origin of colonization of all central sites.

Unfortunately, we were not able to find out which company (or companies) planted junipers and other ornamental plants at sites 2 and 11. Therefore, we do not know whether the great similarity of the phenotypic and genetic composition of these two colonies (fig. 2) is the result of their common origin or habitation in similar conditions.

In contrast to the urbanized biotopes of southeastern Poland (Ożgo, 2005), the colonization of which by C. nemoralis began already at the end of the 19th century (Bakkowski, 1880 ), we were unable to find statistically significant differences in the frequencies of yellow shells at the sites with different degrees of shading. The differences in the frequencies of unbanded and mid-banded shells also did not reach a statistically significant level. More significant were the differences in the frequencies of the phenotype groups distinguished by the intensity of shell pigmentation and irrespective of the character of inheritance of certain phenotypic traits (table 5).

At present, when analyzing potential selective changes in the phenotypic composition of $C$. nemoralis, the frequencies of the phenotypic manifestation of three alleles responsible for the yellow ground color of the shell, the complete absence of bands on it, and the formation of shells with one central band among banded shells are often used (Silvertown et al., 2011). However, with this approach, shells with different intensities of coloration, from very light to very dark, inevitably fall into each of the groups. The latter, for example, may include dark brown shells among unbanded and mid-banded, five-banded shells with fused bands among yellow ones.

Also, this does not take into account the possible linked inheritance of the ground color of the shell and the complete absence of bands on it (Murray, 1975), which may result in the fact that shells with a lighter (yellow) ground color are relatively more often banded, and pink and especially brown shells - unbanded (Schilder, Schilder, 1957; Sverlova, 2007). It is possible that the observed ratio is also influenced by selection, acting against both the lightest and darkest coloration variants (Sverlova, 2004), and which can increase in introduced populations (Sverlova, 2007), up to complete linkage of the yellow color with banded, and pink color with unbanded shells (Gural-Sverlova et al., 2020; Sverlova, 2007).

This approach is especially problematic for introduced and relatively young colonies, the initial phenotypic composition of which is largely dependent on random factors (founder effect as well as gene drift at low snail numbers in recently formed colonies). Even with strong selection, climatic or visual (Jones et al., 1977), further changes in such colonies can occur in different ways, depending on the initial ratio of phenotypes. That is why we believe that it is more expedient to consider the frequencies not of single darkest or lightest phenotypes, but of their aggregates (see Material and methods). 
Table 5. The variability of the phenotypic composition of C. nemoralis in Lviv

\begin{tabular}{|c|c|c|c|c|c|}
\hline \multirow[t]{2}{*}{$\begin{array}{l}\text { Inherited phenotypic } \\
\text { traits }\end{array}$} & \multicolumn{3}{|c|}{$\begin{array}{l}\text { Probable allele frequencies calculated } \\
\text { from phenotype frequencies in } \\
\text { samples }\end{array}$} & \multicolumn{2}{|c|}{$\begin{array}{l}\text { Inbreeding coefficient Fst calculated from the } \\
\text { frequencies of }\end{array}$} \\
\hline & $\min$ & $\max$ & mean & phenotypes $^{*}$ & alleles \\
\hline \multicolumn{6}{|c|}{ Ground color: } \\
\hline Yellow & 0.243 & 0.971 & 0.687 & 0.251 & 0.185 \\
\hline Pink & 0.029 & 0.757 & 0.293 & $(0.310)$ & 0.220 \\
\hline Brown & 0 & 0.184 & 0.020 & 0.233 & 0.127 \\
\hline \multicolumn{6}{|c|}{ Number of bands: } \\
\hline Unbanded & 0 & 0.508 & 0.235 & 0.206 & 0.124 \\
\hline Mid-banded & 0 & 0.628 & 0.217 & 0.335 & 0.224 \\
\hline Three-banded & 0 & 1.000 & 0.231 & 0.570 & 0.654 \\
\hline
\end{tabular}

Note. ${ }^{*}$ Calculated according to Cameron et al. $(2009,2014)$, the value in parentheses is not calculated in the original method.

It is very likely that the weak relationship between the intensity of shell coloration and the degree of shading of habitats in the Lviv colonies of $C$. nemoralis studied by us is caused not only with the above-mentioned random factors, but also with the relative youth of these colonies. In this case, over time, this relationship may intensify which can be confirmed or refuted only by further long-term studies, similar to studies of C. hortensis in Lviv (GuralSverlova, Gural, 2018). However, it cannot be ruled out that the more continental climate of Western Ukraine in comparison with the natural range of $C$. nemoralis will facilitate the selection of relatively light phenotypes even in shaded habitats, as is now observed in C. hortensis.

According to Kirchhoff's law of thermal radiation, light-colored shells, like any other light-colored surfaces, must not only heat up more slowly in the sun but also cool more slowly as a result of their own thermal radiation (Arnason, Grant, 1976; Sverlova, 2004). Therefore, it is assumed that the dark-colored phenotypes of Cepaea should have a selective advantage in cooler, but at the same time relatively stable climatic conditions: in forests, on coasts, etc (Sverlova, 2004). And a lighter coloration can prevent not only overheating of shells in the sun but also their cooling too quickly with a sharp decrease in ambient temperature (Arnason, Grant, 1976). Therefore, snails with light-colored shells can theoretically receive a selective advantage also with sharper temperature fluctuations characteristic of a more continental climate (Sverlova et al., 2006).

\section{Conclusions}

Our studies have shown not only the presence in Lviv of a number of relatively young colonies of the introduced species $C$. nemoralis, but also a great variability of the phenotypic composition within the city, which usually does not have a clear connection with the location of colonies or with the character of habitats.

In the future, the obtained data can be used to monitor possible changes in the phenotypic composition of the investigated colonies to assess the potential effect of selective factors on this composition, first of all, climatic selection outside the natural range of $C$. nemoralis.

\section{References}

Arnason, E., Grant, P. R. 1976. Climatic selection in Cepaea hortensis at the northern limit of its range in Iceland. Evolution, 30, 499-508.

Bąkowski, J. 1880. Mięczaki zebrane w r. 1879 w okolicy Rzeszowa. Sprawozdanie Komisyi Fizyjograficznéj, 14 (2), 254-257.

Boettger, C. R. 1926. Die Verbreitung der Landschneckengattung Cepaea Held in Deutschland. Archiv für Molluskenkunde, 58, 11-24. 
Cameron, R. A. D., Cox, R. J., von Proschwitz, T., Horsák, M. 2014. Cepaea nemoralis (L.) in Göteborg, S. W. Sweden: variation in a recent urban invader. Folia Malacologica, 22 (3), 169-182.

Cameron, R. A. D., Pokryszko, B. M., Horsák, M. 2009. Contrasting patterns of variation in urban populations of Cepaea (Gastropoda: Pulmonata): a tale of two cities. Biological Journal of the Linnean Society, 97, 27-39.

Clarke, B. C. 1960. Divergent effects of natural selection on two closely-related polymorphic snails. Heredity, $14(3-4), 423-443$.

Gural-Sverlova, N. V., Gural, R. I. 2018. Long-term dynamic of phenetic structure in colonies of the introduced species, Cepaea hortensis (Gastropoda, Pulmonata, Helicidae). Zoologicheskij Zhurnal, 97 (7), 751-761 [In Russian].

Gural-Sverlova, N. V., Gural, R. I. 2012-2020. Land mollusks of Ukraine: illustrated database [Electronic resource]. State Museum of Natural History, Lviv. URL: http://www.pip-mollusca.org/page/phg/land/ index.php [In Ukrainian; accessed on 25 November 2020].

Gural-Sverlova, N. V., Gural, R. I., Savchuk, S. P. 2020. New records of Cepaea nemoralis (Gastropoda, Pulmonata, Helicidae) and phenotypic composition of its colonies in Western Ukraine. Ruthenica, Russian Malacological Journal, 30 (2), 75-86 [In Russian].

Gural-Sverlova, N. V., Savchuk, S. P. 2019. Anthropochorous species of land molluscs in Western Ukraine. Naukovi zapysky Derzhavnoho pryrodoznavchoho muzeiu, 35, 49-58 [In Ukrainian].

Jones, J. S., Leith, B., H., Rawlings, P. 1977. Polymorphism in Cepaea - a problem with too many solution? Annual Review of Ecology and Systematics, 8, 109-143.

Lamotte, M. 1951. Recherches sur la structure génétique des populations naturelles de Cepaea nemoralis (L.). Bulletin biologique de la France et de la Belgique. Supplement, 35, 1-239.

Łomnicki, M. 1899. Helix nemoralis L. Kosmos, 23, 382.

Murray, J. 1975. The genetics of the Mollusca. In: King, R. C., ed. Handbook of genetics, 3. Plenum Press, New York, 3-31.

Ożgo, M. 2005. Cepaea nemoralis (L.) in southeastern Poland: association of morph frequencies with habitat. Journal of Molluscan Studies, 71, 93-103.

Schilder, F. A., Schilder, M. 1957. Die Bänderschnecken. Eine Studie zur Evolution der Tiere. Schluß: Die Bänderschnecken Europas. Gustav Fischer Verlag, Jena, 93-206.

Schnetter, M. 1950. Veränderungen der genetischen Konstitution in natürlichen Populationen der polymorphen Bänderschnecken Verhandlungen der Deutschen Zoologischen Gesellschaft, 13, 192-206.

Silvertown, J., Cook, L., Cameron, R. et al. 2011. Citizen science reveals unexpected continental-scale evolutionary change in a model organism. PLoS ONE, 6 (4), 1-8.

Sverlova, N. V. 2002 a. The influence of anthropogenic barriers on phenotypical structure of populations of Cepaea hortensis (Gastropoda, Pulmonata) under urban conditions. Vestnik Zoologii, 36 (5), 61-64 [In Russian].

Sverlova, N. 2002 b. Einschleppung und Polymorphismus der Cepaea-Arten am Beispiel von Lwow in der Westukraine (Gastropoda: Pulmonata: Helicidae). Malakologische Abhandlungen aus dem Staatlichen Museum für Tierkunde Dresden, 20, 267-274.

Sverlova, N. 2004. Landschnecken-Farbpolymorphismus aus physikalischen Gründen (Gastropoda: Pulmonata: Stylommatophora). Malakologische Abhandlungen aus dem Staatlichen Museum für Tierkunde Dresden, 22, 131-145.

Sverlova, N. V. 2005. Variability of the polymorph structure of the urban colonies of the introduced species Cepaea hortensis (Gastropoda, Pulmonata). Vestnik Zoologii, 39 (4), 29-34 [In Russian].

Sverlova, N. V. 2007. Peculiarities of polymorphism structure of introduced populations of Cepaea nemoralis. In: Faltsfeinivski chytannia. P. P. Vyshemyrskyi, Kherson, 287-292 [In Russian].

Sverlova, N. V., Khlus, L. N., Kramarenko, S. S. et al. 2006. Fauna, ecology and intraspecific variability of land molluscs under urban conditions. State Museum of Natural History, Lviv, 1-226 [In Russian].

Taylor, J. W. 1914. Monograph of the land \& freshwater Mollusca of British Isles. Zonitidae, Endodontidae. Helicidae. Taylor brothers publishers, Leeds, 1-522.

Received 2 December 2020

Accepted 5 January 2021 